Copyright (C 2018 Sage. Reprinted by permission of SAGE Publications.

Forthcoming in Environment and Planning C (2018)

\title{
Examining Regional Competitiveness and the Pressures of Rapid Growth: An interpretive institutionalist account of policy responses in three city regions
}

Krueger, $\mathrm{R}^{1}$, Gibbs, D $\mathrm{C}^{2}$ and Carr, $\mathrm{C}^{3}$

${ }^{1}$ Social Science and Policy Studies, Worcester Polytechnic Institute, Worcester, MA, USA.

${ }^{2}$ Geography, School of Environmental Sciences, University of Hull, UK.

${ }^{3}$ Institute of Geography and Spatial Planning, Université de Luxembourg, Luxembourg.

\begin{abstract}
:
This paper is premised on the notion that actors play a central role in shaping their institutional contexts. The paper adds to scholarship in this area by bringing together three disparate cases with a common analytical entry point: the city region. Despite their multiple scales and different sites of governance, these cases are united by a common theme, exemplified in each city region: addressing the contradictions of rapid development, in particular rapid growth and competitiveness. Using the conceptual framework of interpretive institutionalism we examine how dilemmas, in this case the pressure of rapid growth in regions, are informed by the different traditions for understanding the role of the market in delivering project outcomes. Our findings show this difference in institutional norms and the variance amongst the different paradigms.
\end{abstract}

Keywords: growth, sustainable development, interpretive institutionalism, city regions

\section{Introduction}

For some time, economic geographers have understood that what drives human motivation is not necessarily informed solely by assumptions of the profit maximizing rational actor. For them, economic norms are embedded in culture and vary among different places and times (Barnes, 1996; Gertler, 2003; Peck, 2010). Economic norms are thus concrete and empirically observable. For instance, Polanyi argued that economic decision-making is embedded in, and structured and guided by, formal and informal patterns, or institutions. Using a Polanyian lens, Peck (2013) argues that institutions are not universal, but culturally created through tensions embedded in different places and times. Following North (2015: 309), "economic life does not stand apart from, but is an adaptation to and embedded in, wider environmental, societal, and material conditions". Interpretive institutionalism takes a holistic view of meanings and locates them in a wider web of such meanings (Bevir and Rhodes 2006). In this paper we bring the framework of interpretive institutionalism, with its relational approach to dilemmas, traditions, and beliefs, to bear on these approaches within economic geography. In doing so, the contribution of this paper is to show clearly the nuances that cultural embeddedness brings to the regulatory function of the market. 
Interpretive institutionalism, which was developed in political science by Mark Bevir and Roderick Rhodes (2001), can bring valuable insights into the dynamics of how actors draw upon their milieu to shape institutional responses to problems (or in their language 'dilemmas') such as reconciling sustainability and markets through their traditions and beliefs. This framing of institutions comes from an interest in institutional formation outside the geographical political economy literature. In some studies of institutions, institutional form tends to be separated from the actors who inhabit them in a search for a deductive link between institutional form and function. For example, in the policy studies literature 'rational choice institutionalism' maintains a dominant hold on institutional theory (Durant, 2006). Here, scholars rely on the "inviolable" assumption of neoclassical economics - that bureaucrats are rational actors acting in their own self-interest, which is institutional preservation. Regardless, embedded approaches have emerged. A study by Zegart (1999) focused on the strategic role of bureaucrats in the alignments and realignment of governmental institutions (see also Krause and Meier, 2005). Similarly, Durant (2006: 470) noted that such "studies find that bureaucrats act strategically to influence agency design and evolution; they are not passive bystanders who are merely 'acted upon' as most conventional principal-agent models assume." In the British politics literature, a networks approach is a common analytical tool for measuring institutional change. Here the concept of embeddedness is critical, thus the role of cultural norms and institutional structures are vital for exploring social life (Bevir, 2006; Coaffee and Healey, 2003). Where some might opt for upholding assumptions about utility maximizing actors, these social scientists argue that agents are embedded in institutions and that networks are key drivers in policy expressions and outcomes, which are contingent and often unintended. For example, Rhodes (1997) found that neo-liberal reforms in Britain during the 1980s fragmented service-delivery, thereby weakening central control because they did not establish proper markets, revealing the unintended consequences of policy implementation at a bureaucratic and governance level. In short, an interpretive institutionalist approach suggests that institutional forms and models alone cannot reveal institutional functionality (or dysfunctionality). Only when we study beliefs and practices as mutually constitutive of one another can we begin to do so.

Bevir and Rhodes' work has opened up the black box of institutions to show how these factors, held by a broad coterie of economic actors, shape institutions, and, in relation to the focus of this paper, market-oriented policies for addressing rapid growth. This work fits with the Polanyian perspective in that it captures the tensions referred to by Peck (2013). As with the case of cultural economic geography, which has made linguistic (Gibson-Graham 1996), historical (Barnes 1996), and pragmatist turns (Barnes and Sheppard 2013), interpretative institutionalism examines patterns of human behaviour as they shape the very policy contexts in which they exist. Relying on a conceptual framework that privileges actors affords a tighter focus on how economic life is shaped by those actors seeking to make sense of the world around them. It is similar to interpretative policy analysis in that it challenges the top-down, instrumental rational model of policy-making and implementation. For Yanow (2017; 403) interpretative policy analysis asks not only "what a policy means but how policies mean -questions about process by which meanings are communicated". While interpretative institutionalism can examine, say, the land use planning policies of the UK central government (see below), the focus remains on the actors within institutions and how they make sense of their policy context.. For us a key distinction between interpretative policy analysis and interpretative institutionalism is that the 
latter focuses primarily on the conditions of policy development, where the former often focuses on implementation.

In this paper, we employ three concepts (dilemmas, traditions, and beliefs - see below), though primarily the first two because of the nature of the study, to explore three very different responses to the same problems (or dilemmas) of rapid development in three dynamic economic spaces - Boston city-region, London and South East England, and the cross-border agglomeration of Luxembourg. While the narratives that are associated with each case reflect the similarities of the dilemmas facing these three locations, differing traditions and beliefs have led to different policy and institutional outcomes. From this, we can see how actors in different places understand the mechanics of economic competition and growth differently and seek to regulate them accordingly. Our cases were chosen because they represent three dynamic and rapidly changing city regions that are regulated at a variety of spatial scales, yet where the process of 'meaning making' is not so different. Whether local government in Boston, devolving central government in the UK, or the strong regulatory state in Luxembourg, actors take on broad narratives of rapid development, develop potential responses to it, and shape them in their own interpretivist way. The paper therefore contributes to the literature on cultural embeddedness and interpretative policy analysis in that it provides a robust conceptualization for how actors borrowing from their worlds deploy more general mobilized ideas and ideologies.

To make this argument our paper unfolds as follows. In the next section, we examine interpretive institutionalism and its conceptual contributions that add to cultural theories of economy. In the following two sections, we examine issues related to the rapid growth of competitive city regions and the policies that different places have sought to ameliorate these issues and then describe the methods we used to collect the data for the case studies. The next section provides details and analysis of our case studies. Finally, we pull the argument together in a concluding section.

\section{Interpretive Institutionalism}

Institutions are entities with social origins and underlying ideologies. As several scholars have noted, current neoliberal institutions have their roots in earlier social histories (Mansfield, 2004; Peck, 2010) and ideologies that may contradict current formulations of neoliberalism (Raco, 2005). The role of ideology in shaping institutional outcomes is an important one. But ideology is not employed equally across space, e.g., to pull an analogy from Regulationism: there is not just one capitalism, but 'capitalisms'. A post-structural view of institutions posits that institutions are not merely containers of historical perspectives and actions; rather, they focus on the dynamic and contingent role of actors in shaping institutional responses (González and Healey, 2005; Irazábal, 2005). This analytical approach addresses what for many is a common problem with institutional analyses: it takes 'institutions for granted and treats them as if the people within them are bound to follow predetermined procedures or rules, rather than respond to them through their own contingent agency' (Irazábal, 2005: 44). However, 'ideas on their own cannot influence the shape of institutions . . . ideas need carriers - individuals and interest groups who advocate in their favour, and develop strategies for their promotion' (Lowndes, 2005: 297). Actors shape outcomes and agendas through struggle, conflict, encounter, and resistance (González and Healey, 2005; Lowndes, 2005). Here institutional analysis can be exposed to sources of power, gender inequality, the politics of science, and the like. 
Interpretive institutionalism provides a framework to examine the way institutions are created, sustained or modified through the ideas and actions of individuals (Bevir 1999). The actions of individuals are therefore not governed by their institutional position or institutional rules; rather, the analytical lens focuses on 'how meanings and actions, are created, recreated and changed in ways that produce and transform institutions' (Bevir, 2003: 460). Economic actors and firms, for example, create institutions as a set of broader social processes as well as the agency of actors working to construct them and act through them. Institutions can be seen not only as administrative and political organizations, but also as 'the rules, norms and practices, which structure areas of social endeavour' (Coaffee and Healey, 2003: 1982). Hence, 'institutional rules may be consciously designed and clearly specified (as in structural plans and operating procedures) or take the form of unwritten customs and conventions (as in aspects of 'professionalism' or 'departmentalism')' (Lowndes and Wilson, 2001: 632). Bevir's (1999) analysis of the New Labour Party in the UK, for example, shows that New Labour appealed to the discourse of socialism in terms of its core values, but sought new ways of realizing those values in the context of the changing circumstances of the 1990s. As a rhetorical move this may have been New Labour's goal, yet, as a political analysis, socialism remained a trans-historical account of "human nature" with temporally fixed ethical commitments. In this case, then, socialism is a fixed, trans-historical object of analysis set against a backdrop of particular contexts. For Bevir, a non-reified model of ideology refuses to ascribe to it an existence of the particular beliefs and actions of individuals (Bevir, 1999).

This argument and evidence suggests that a more nuanced understanding of those contemporary institutions, the scale of which is contingent (see below), responsible for addressing the dilemmas of rapid growth is warranted to understand the specific policy responses in different locations. It renders problematic the notion that institutions arise from 'given inputs, pressures and policies' (Bevir and Rhodes, 2001: 21). According to Bevir and Rhodes (ibid.: 21) institutions do not:

arise from given pressures that require movement towards the minimal state, marketization, and the new public management. On the contrary, state-actors construct both their understanding of the pressures or dilemmas, and also the policies they adopt in response to them, in perhaps different ways depending on the background of which they do so.

Bevir and Rhodes are ultimately interested in individual political actors and their decision making. In this paper, we focus less on how political actors are informed and more with how they apply that information and knowledge through institutional practice and thereby mediate institutions in ways that might transcend labels such as 'neoliberal' or 'Fordist'. Following DiGaetano and Strom (2003: 372) we suggest that 'political actors are the carriers of culture, and their understanding of the structural context and institutional milieu is affected by the values and beliefs that they hold'. We are not interested in agency alone, but with how historically and culturally embedded actors make sense of the structures around them and forge relationships they see as necessary to fulfil their policy goals (Bevir, 2006). Thus, an interpretivist account 'encourages us to examine the ways social life, institutions and policies are created, sustained and modified by individuals acting upon beliefs that are not given to them by the institution itself 
or a universal rationality' (ibid.: 461). In terms of the research presented here, we are interested in how different actors, in three different city-regions, have addressed a similar problem or dilemma with very different outcomes. In particular, this research gives us the opportunity to develop the concept of "traditions" from a geographical perspective.

There are conceptual differences, as well as methodological ones, for analyzing institutions in this way. Space prohibits us from covering all these nuances (see Yeung, 2003, for more detail), but we do wish to make two distinctions. First, an interpretive analysis of institutions shifts away from the meta-narrative in the first instance. Rather, the analytical entry point is like examining 'a political contest based on different webs of belief' (Bevir and Rhodes, 2001: 18). Commentators from a Marxist and regulationist orientation were critical of the historically dislodged concepts of neo-classical economics, such as rational actors, perfect information and wealth maximization, complaining of their positivist underpinnings (Barnes, 1996), yet have allowed for certain conceptual obfuscations, such as those we have discussed here, to continue. This position reflects the sensibility of new economic geography. As Thrift and Olds (1996: 319) declare, 'the very idea of a singular story of an object denoted "economic" is now lost'. Moreover, an interpretive analysis requires a closer understanding of actors involved in the process transforming the economy-environment relationships involved in urban sustainability. An interpretive institutional analysis establishes the internal politics of institutions, as well as the external forces that shape them, as an open question. No longer can we accept the position that institutions are merely the containers of a regime's hegemonic ideology. Rather, we need 'to study deeper frames of reference and cultural practices which structure how people make sense of their collective worlds and engage cognitively and bodily in their day-to-day routines' (González and Healey, 2005: 2059). Table 1 provides details and definitions of the key elements of each analytical concept (see Gibbs and Krueger, 2012; Krueger and Gibbs, 2010, for a more detailed discussion).

\section{(Table 1 about here)}

\section{Policy Responses to Rapid Growing City Regions}

In this section of the paper we turn to an examination of our three case study regions. Each of the cases presented below represents a city region that has experienced a rapid growth in economic activity in recent years and a (perceived at least) decline in competitiveness. While the former has brought benefits in terms of growing income (for some) and employment, it has also led to a common set of problems. In all three cases, lack of affordable housing and dwindling open space were considered to be key policy dilemmas facing the region. These are not the only regions to face such concerns, similar concerns exist in Kenya (Midheme and Moulaert, 2013), Tel Aviv, (Marom, 2014), Singapore (Olds 2001), Vancouver (Rosol, 2013), Dortmund (Frank, forthcoming), Boston (Gibbs and Krueger, 2012), and, of course, throughout China (Chang and Sheppard, 2013). For policy makers, one of the key tensions in the management of such growing economies is that between maintaining economic competitiveness and preserving the quality of life, especially for the kinds of entrepreneurial talent vital for the types of high tech and high level service sector activities upon which their economies depend. Thus, key workers in such 
sectors are particularly sensitive to environmental amenities, services and assets offered in these places, as well as access to good schools, health care and the like. By definition, city regions with high growth often engender conditions that threaten conditions of social reproduction (Jonas et al., 2010). One attempted 'solution' to these dilemmas has been for policy makers to adopt policies based around the concept of sustainable development which have, for them, attempted to reconcile economic development with the preservation of environmental assets. From the late 1990s onwards, sustainability as a rhetorical strategy became a key part of many city-regions' development strategies. However, the particular form that sustainability took in different locations can partially be explained by the political economic positioning of the "sustainable city" and the growing view amongst policy makers that the sustainable city can be an engine for economic growth (Krueger and Gibbs, 2010; Gibbs and Krueger, 2012). We utilize our three case studies to explore in geographic terms how non-market actors, at different spatial scales, have exerted power over the sustainable development discourse and linked it to the larger context of market-based reform. Similarly, we employ interpretative institutionalism to show that while policy dilemmas may seem the same, in this case rapid growth and stress on housing stock and environmental amenities, how different institutions confront these and develop responses can be very different.

\section{Methods}

While the dilemmas in the case studies are similar in character, the policy responses and management forms are decidedly actor informed. For example, the Boston case is focused on market-oriented forms of governance, in London and the South East of England power is retained by central government, albeit mitigated through housing targets, market based incentives, and penalties for local authorities who do not allocate enough land for housing. Finally, in Luxembourg, central government maintains significant power by developing a traditional command and control regime of governance. These approaches, from neoliberal, to third way, to classic state intervention, represent key existing paradigms for land use planning in cities around the world. Yet, we cannot assume that these were chosen as part of some sort of inherent "maximizing" behaviour. Further, as the cases will illustrate there is no "pure" paradigm, they are all mitigated by the traditions and beliefs of key actors involved in developing and implementing them. Thus, while the dilemmas are similar, traditions and beliefs are placespecific, and the actors within these places pick and mix responses based on their own understanding of these problems. Thus, we seek to respond to Peck's (2004) call to move beyond specific articulations of neoliberalism to a generalizable approach. For Peck (2004: 399), “ the challenge here is to make sense of specific articulations between such local neoliberalisms and neoliberalism-in-general, not to privilege a certain kind of transition ... [or] unidirectional process of diffusion from dominant 'centers' in Chicago or Washington, DC" (emphasis ours). Indeed, our cases provide a detailed examination of how these flows of ideas are transformed when they arrive in new policy-state-actor contexts.

Our research in these areas has been ongoing over a period from 2006 onwards ${ }^{1}$. In Boston,

\footnotetext{
${ }^{1}$ The interview process took place between 2006-12 and we have continued to monitor these places through secondary data analysis. The interview data collected from 2006-2012 remains
} 
interviews were conducted with 15 respondents from the state regulatory authority, regional planning boards, NGOs, and key political officials in the Romney Administration. In London and the South East, over 20 people were interviewed from central government ministries, (former) regional planning bodies, local authorities, professional planners and members of the Town and Country Planning Association, as well as the Royal Society of Architects, and the Centre for Cities. In Luxembourg, we interviewed 25 people in regional planning agencies, central government ministries, national and local NGOs, expert elites in the area of planning and development in Luxembourg, and experts from quasi-governmental organizations. In addition, to these interviews we have analysed secondary sources, such as white papers, planning policy documents, and demographic data. Our research design was iterative in nature. We started the research process by educating ourselves through the secondary and grey literatures. Here we examined transcripts of policy debates, white papers, position papers, and the like to understand the genre of policy dilemmas, before proceeding to the interview stage.

\section{Case Studies: the problem of rapid growth, environmental degradation, and competitiveness}

\section{Using the Market to Manage the Boston Region's Dilemmas from Rapid Growth}

The Boston region's economy is based upon research and development (R\&D) in local institutions of higher education and health care, as well as the wider services sector. In institutionalist terms, the key dilemma that has confronted Boston's policy makers is how to maintain the quality of life that has attracted such new economy firms and their workers, yet at the same time deal with the planning consequences (Gibbs and Krueger, 2012; Murphy, 2015). In particular, the cost of housing and problems over affordability have forced actors to consider the appropriate institutional forms to deal with land use planning problems. Boston's economic success and land use regulation have led to development further and further from the city itself, resulting in sprawl and traffic congestion. Sprawl has led to loss of open space and agricultural land, and placed severe strain on water availability (Metropolitan Area Planning Council (MAPC), 2007). The reconciliation of the two issues of sprawl and housing availability adds another layer to the dilemma, as the following quote illustrates:

We live in a very desirable region. The quality of life offered by our historical, cultural, natural, and economic attributes continues to retain residents and draw increasing numbers of people to make their homes here. As the number of households in Metropolitan Boston is rising, we are all - long-time resident and newcomer alike - placing increasing demands on the infrastructure that supports our quality of life. Indeed, we appear to be jeopardizing many of the attributes that drew us here in the first place (MAPC 2006).

While Boston needs more and affordable housing to retain and/or attract new-economy workers, this has resulted in suburban sprawl that destroys the sense of place that attracted these same firms and workers in the first place. Policy makers in Boston have constructed these dilemmas as

highly relevant as, after the credit crunch, the dilemmas of housing and pressure on green space remain in each of these city regions and, if anything, have been exacerbated. 
being almost entirely economically-driven and about maintaining global competitiveness. Concerns over preserving open space and environmental assets are present, but these are framed in such a way that they are mainly seen as important for retaining and attracting economic activity. As an interview with a high ranking government official attests:

In Massachusetts, the number one issue for employers has been affordable housing. This is the top way the business and SG [smart growth] agendas have aligned and gone forward together in Massachusetts. Business says they can't get as much house as they're used to, close in. Some companies won't relocate here, especially those who come from the Southern US. So the smart growth agenda has become a housing production agenda, but it's been to increase housing in smart locations: near transit, near downtown. So you increase the supply of housing, which will in turn have a moderating effect on housing prices (Interview, Romney Advisor, 2006).

Thus the institutional response to these dilemmas has been the adoption of smart growth principles intended to allow continued growth and increased housing availability, while maintaining the attractiveness of a New England location. Like sustainable development, smart growth 'leverages new growth to improve the community... It also preserves open space and many other environmental amenities' (Anderson, 1998: 4). To accomplish these tripartite goals smart growth policies tend to promote development that has the following characteristics: highdensity development around public transport nodes, development that occurs in older suburbs and inner cities and mixed land uses (retail, commercial and residential).

However, two particular traditions are important in understanding the ways in which actors have framed smart growth responses. These are political fragmentation (or 'home rule') and affordable housing. First, one of the key issues in the Boston city-region has been to develop a region-wide response to the dilemmas and to transcend local traditions of home rule at the municipal level. Massachusetts has 351 cities and towns, each with their own land use regulations and local governments have broad discretion over zoning and rely heavily on property taxes for funding (Horan, 2009). A key institutional response was the initiation of the 'MetroFuture' project in 2002 by the Metropolitan Area Planning Commission (MAPC), the regional planning entity for Boston and its 100 surrounding towns. MAPC (2008) makes the point that individual responses at the municipal level cannot solve regional problems and that cooperative planning at the regional level is the only way to address the scale and complexity of the city-region's problems - the dilemmas involved necessitate a shift in tradition away from fragmentation. While for some the tradition of 'home rule' needs to be transcended, any attempt to modify institutional forms has had to rely on greater engagement with municipalities.

What we are seeing here is that, 'at the heart of [the] notion of tradition are individuals using local reasoning consciously and subconsciously to reflect on and modify their contingent heritage' (Bevir et al, 2003: 109). MetroFuture represents a smart growth approach to break down existing local traditions whereby transportation, housing, water resources, health and education were considered separately (and often within separate institutional silos) to considering these in a holistic and coordinated manner. The MetroFuture regional plan is based on smart growth principles involving greater amounts of regional cooperation, directing growth 
to high density, transit-oriented locations, using brownfields and reducing energy, car and resource use (see MAPC, 2008). A director at an NGO, the Arc of Innovation, addresses the problem this way:

Sustaining natural resources is crucial to any economic development strategy... The Commonwealth and much of the industrialized world have moved from a manufacturing to an information based economy; because of this shift knowledge, embodied in people, is the new raw material. Knowledge workers value the environment as an important quality of life asset and they choose to live in places that value it as well. Because workers, with their knowledge and skills, are so important in today's economy, firms will locate to these places to tap into their talent. A healthy environment and its preservation must be viewed as a key component to any comprehensive economic development strategy (ARC, 2007).

Second, in relation to the affordable housing question, the former Office of Commonwealth Development (OCD) and the State Legislature attempted to address this dilemma through legislative changes, creating new institutional forms. The major attempts to do this built upon long-standing traditions of influencing market-based approaches and creating affordable housing. Thus, Chapter 40B, the Massachusetts Comprehensive Permit Law of 1969, has long required $10 \%$ of housing stock in each municipality to be set aside as affordable housing for lowand moderate-income families. In 2004 and 2005, however, the State Legislature passed amendments to the affordable housing statute that included certain 'smart growth' components. Chapter 40R, the Smart Growth Zoning and Housing Production Act addressed the issue of restrictive zoning in many of the city-region's constituent municipalities that permit large, single-family homes on one-acre lots, while prohibiting multi-family homes, apartments and accessory apartments. The state aims to provide incentives for developments that use existing developed sites (not open space), or are in areas with existing infrastructure or near transit terminals. The Act also requires that $20 \%$ of housing at these sites has to be 'affordable'. A transit-oriented development (TOD) program supports housing near public transit, cycling and pedestrian amenities, with the aim of managing parking, reducing traffic congestion and improving air quality. Finally, the Commonwealth Capital program, introduced in 2004, linked funding allocations for roads, sewers, parks and so on (nearly US \$500 million annually) to a sustainable development checklist, intended to provide incentives for municipalities to alter land use practices. What we see here, then, is how a long-standing liberal tradition of state intervention to produce affordable housing has been retained through 40R in order to address contemporary dilemmas. At the same time, though, the Commonwealth Capital program and Smart Growth Tool Kit rely on market-based incentives.

In the process of framing dilemmas economic development and housing-cost arguments are ones that have resonated most strongly with the beliefs of key state politicians and business interests. However, beliefs around smart growth only gained traction in the late 1990s and early 2000s amongst politicians. It was only when smart growth ideas gained both local and national prominence that planners felt able to incorporate these into policy perspectives in the guise of MetroFuture. The formation of MetroFuture involved a substantial effort to enrol other sets of local actors into these beliefs through a series of presentations, workshops, surveys and newspaper polls in order to incorporate a wide set of concerns. While this had some success, 
with over 4,500 people and organizations involved in meetings and consultations, there has been limited business community engagement. As a result, Boston has not been able to create a strong culture of participation in land use or development affairs outside the typical pathways. This has meant difficulty for those engaged in the smart growth project to involve this set of actors in constructing a response to dilemmas. When dilemmas are addressed, therefore, it may be that only certain beliefs 'matter' in relation to Boston's new institutional formations, or at least in the sense of active engagement.

\section{Devolving Growth Management in England's South East}

Since the late 1990s, when the New Labour Government took control of the UK Parliament, the concept of sustainable development has had a conspicuous role in attempts to reconcile the challenges brought by rapid regional economic growth in London and South East England. From 2010, under the subsequent Coalition government, the commitment to sustainable development continued as the London and South East continued to act as a main driver of the UK economy, albeit that the delivery mechanisms and targets employed altered. It is also worth noting that the Central Government remains delegator of regional policy in the UK, which is why we are examining the London city region based on Central Government policy. In this section we examine the rhetorical moves each government employed in order to manage the pressures of rapid growth in line with its understanding of the policy dilemma, party traditions, and the beliefs of different key actors.

\section{New Labour and Sustainable Development: Internalizing Externalities}

As the century came to a close, sustainable development in UK cities became a key response to the similar dilemma we have outlined in Boston - how does a city or region reconcile economic growth and environmental protection? The dilemma was especially acute in South East England, where population growth put extraordinary pressure on housing costs and quality of life issues, in the context of increasing housing scarcity and a slow planning process. As in Boston, the dilemma was framed as maintaining the region's competitiveness and a similar policy response argued that developing a "sustainable city-region" could be an engine for economic growth, not a hindrance to it. In addition, this dovetailed with a policy shift away from regional redistribution as a source of competitiveness towards a greater emphasis on city-regions as drivers of the economy (While, Gibbs and Jonas, 2013). The dilemma was captured in Kate Barker's report on the 'housing issue' that exposed the tension between planning practices in local authorities and the time it takes to deliver housing to the market place. For Barker, there were issues around the relationship between the private sector as the main deliverer of housing, which may not accord with government objectives (Barker, 2004: i). Here, Barker, and many others, were taking aim at what they saw as an antiquated planning system which dated back to the Town and Country Planning Act of 1947 which, in many commentators' views, gave local authorities far too much power in opening up - or not opening up - land for development. Thus politicians criticised the planning system as being outdated and overly burdensome for developers, as the following quote indicates:

While there are policies to bring a higher level of professionalism to planning, the real problem is some of the ageing planners. These planners had lost their power 
under Thatcher and wanted to go back to the old ways. Thus they needed to be given incentives to open up lands for housing through the local development frameworks (Personal communication, LDA, 2008).

Using the language of interpretive institutionalism, the dilemma was how to maintain London and the South East's competitiveness under conditions of a failing factor of production in the city-region i.e., urban socio-environmental quality of life. New Labour viewed this dilemma in the tradition of Labour's goal for redistribution and fairness. In order to address the dilemma, in 1998 the then Office of the Deputy Prime Minister (ODPM) commissioned the London "Starchitect" Richard Rogers to lead an Urban Task Force. Urban regeneration was to be guided by three key principles: design excellence, social well-being, and environmental responsibility. These principles come from the Labour party's tradition of socialism, or distribution of wealth and quality of life among different social groups. This expression of values was stated in the subsequent ODPM's Planning Policy Statement 1 (PPS 1) where the ODPM outlines four clear goals for developing sustainable cities:

1. Progress that recognized the needs of everyone;

2. Effective protection of the environment;

3. Prudent use of natural resources, and;

4. Maintenance of high and stable levels of economic growth and employment.

A series of policy measures were announced and handed down to local authorities in order to respond to the perceived policy dilemmas (for a more in depth study of these institutional changes in the UK planning system see Krueger and Gibbs (2010) and Allmendinger (2011). One particular response was to shift thinking away from a public service tradition towards an economic focus:

Folks were forced to think about resource allocations as economists, that was the place for the market. When externalities were identified, here was where the state would carve out space for institutional intervention (Interview, Former Communities and Local Government staff member, 2009).

Finally the belief was that more housing would resolve much of the tensions if it were made available through a more efficient planning system and developed faster to meet growing demand, but while maintaining the traditional policy goals of the (New) Labour Party. To further illustrate this point, we will look at some of the subsequent Conservative-Liberal Democrat Coalition Government reforms and how they extended these provisions given the different traditions and beliefs they were informed by.

\section{The Coalition Government and Sustainable Urban Development}

The Coalition Government partially repealed Labour's Planning and Compulsory Purchase Act of 2004 and introduced the National Planning Policy Framework (NPPF) in 2012. The London Plan, first introduced in 2004, was also amended to comply with the NPPF. The NPPF added new goals to the planning system, with the top three focused on economic growth. These are: 
1. Building a strong, competitive economy;

2. Ensuring the vitality of town centres;

3. Supporting a prosperous rural economy.

While the Coalition Government developed its own definition of sustainable development in the NPPF, this also stresses the Government's belief in the 'growth imperative':

"the purpose of planning is to help achieve sustainable development. Sustainable means ensuring that better lives for ourselves don't mean worse lives for future generations. Development means growth. We must accommodate the new ways by which we will earn our living in a competitive world. We must house a rising population, which is living longer and wants to make new choices" (NPPF 2012, page ii).

The NPPF abolished Regional Development Agencies as a tier in the planning regime. This decentralised planning from the regional scale to the local scale through Local Enterprise Partnerships. Through the Localism Act of 2011, Central Government called for local planning organizations to become more involved in neighbourhood planning practice. The Act also wound up the London Development Agency which had been responsible for development across London and responsibility passed to the Greater London Authority, established in 2000, in conjunction with the London boroughs. This may sound like a more democratic approach than under the previous regime and clearly defines those organizations accountable for planning decisions. However, the devolved response was limited given that the NPPF also introduced a number of caveats in favour of development. For example, the Planning Inspectorate (Planning Inspectorate, 2012) published guidance regarding the approval of local plans:

The Council ... will always work proactively with applicants jointly to find solutions which mean that [planning] proposals can be approved wherever possible, and to secure development that improves the economic, social and environmental conditions in the area. Planning applications that accord with the policies in this Local Plan (and, where relevant, with policies in neighbourhood plans) will be approved without delay, unless material considerations indicate otherwise. Where there are no policies relevant to the application or relevant policies are out of date at the time of making the decision then the Council will grant permission unless material considerations indicate otherwise.

Coalition responses to the dilemma thus supported those which were defined by New Labour efficiency in the approval process, pressure on planning authorities to approve development plans, and on changing material conditions. First, local authorities were required to "always work proactively with applicants". This keeps the decision making more 'local' because the appeal process to regional authorities has been abolished. The only opportunity for appeal is to the Department of Communities and Local Government (DCLG), which seems to be a decidedly 'pro-growth' approach given that DCLG was the organization that promulgated the NPPF in the first place. Similarly, the language in the policy states that: "planning proposals can be approved wherever possible." Then, in the second clause, it states "and to secure development that..." This is written as if improvement to the economic, social and environmental conditions to an area is 
aspirational and not a requirement. Second, the language of 'material conditions' is again employed. Here, material conditions are not well-defined, thus, in the case of a conflict between the interests of the local authority and the project proponent, DCLG are the final arbiter of what constitutes material conditions. Thus, while the local authorities have primacy in local planning activities, even down to the neighbourhood scale, they are constrained by the more explicit language to grant planning permission.

Support for this argument exists elsewhere in the NPPF which calls for a significant boost in the supply of housing approved by local planning authorities, provision of development sites for five years' worth of housing needs, and longer term housing projections. Such provision was seen as especially acute in London and the South East where there were shortages of affordable housing. However, as with the clause regarding improvement to environmental conditions outlined above, the NPPF suggests that affordable housing is welcome, but not required. Affordable housing must be provided on site "unless off-site provision or a financial contribution of broadly equivalent value" can be obtained" (NPPF, 2012: 12-13). Overall, market-based housing, favoured by private developers, receives the greatest emphasis.

In summary, the goal of New Labour policy was to create development markets and, in principle, monitor externalities. By contrast, the Coalition Government's goal was to re-emphasise the need for rapid development by requiring that plans be adopted, setting housing targets without the requirement for an affordability component, and limiting the appeal process to one arbiter. This analysis of the Coalition Government's policies illustrates how differences in tradition affect the response, even when there is an agreement on the dilemma. Whereas New Labour sought to promote explicitly its social goals and created a set of institutional conditions to support them, the Coalition Government employed its own tradition of market-oriented approaches, instead of command and control, to regulate property markets and modernize planning. Despite these different approaches, the major dilemma of housing provision remained (and remains) preeminent. Devolution of responsibility to local authorities and, in the case of London, to the Greater London Authority and the London boroughs, has not produced any notable increase in affordable housing provision (see Mayor of London, 2017).

\section{Reinforcing the Centralized State Apparatus in Luxembourg}

Finally, we turn to the Grand Duchy of Luxembourg. This case further illustrates the role of tradition in shaping actors' understanding of dilemmas. Located between Belgium, France, and Germany, Luxembourg is a sovereign small state whose economic activities have social spatial effects that spill across the national borders into all three neighbouring countries (Chilla and Schulz, 2015), forming a cross-border urban agglomeration (Carr, forthcoming), or "enclave space" (Hesse, 2014). Due to this cross-border character, and because Luxembourg's policies have direct impacts in the border regions, there is good reason to examine socio-political and institutional responses generated in the regions beyond Luxembourg's borders. However, the focus here is on national policy-making, how policy-makers construct their dilemmas, and how these are embedded in traditions that are specific to the Grand Duchy.

For decades following World War II, Luxembourg relied on iron ore mining, metal processing, and value added steel products as the basis of its economy. Economic restructuring, however, left 
Luxembourg with a much smaller 'boutique' steel industry and the nation had to look for a new basis of accumulation. The cross-border urban agglomeration observable today is the consequence of political economic strategies that aimed at attracting European Union offices, encouraging development of the financial, service and R\&D sectors, and most recently development as an important node in the international geographies of both IT development and the space industry. As a result, the country has been managing continual growth pressure since the late 1990s.

As with the other two cases, the key dilemma in Luxembourg is how to manage the challenges associated with rapid growth while maintaining quality of life (Affolderbach and Carr, 2016; Hesse and Becker, 2010). Inward migration of both labour and businesses have heated the private property market, and driven up the value of land. The consequences of this are illustrated in the following quotation:

The pressure is very high. The pressure doubles every year. You wouldn't believe, for example, that we just organized a workshop for the administration on how to deal with construction and demolition waste. The amount of waste that has to be disposed of is increasing, dramatically, each year. In part, this has to do with the fact that everything has to be built densely. But what about parking? What do they do about that? They build two, three, or four underground levels. This situation is not going to improve. So, there are severe consequences and costs associated with the pressure. It means, too, that the pressure on the property development is extremely high, and come hell or high water, properties will be exploited as far as possible. And that drives the prices higher up again (Interview, Architect, 2012).

While property owners welcomed increased property values, higher prices proved problematic for renters and first-time buyers looking for a certain standard of living. Many workers, including Luxembourgish citizens, find it more affordable to settle in the neighbouring regions of Lorraine (France), Rhineland Palatinate (Germany) or Wallonia (Belgium), where the combined costs of housing and commuting is still cheaper than housing locations inside Luxembourg (Christmann, 2017). The resulting settlement patterns lead to new dilemmas, because increased numbers of cross-border commuters put strain on existing transport infrastructures that connect the border regions to Luxembourg. Jammed highways and slow and over-packed commuter trains remain the norm.

Within the Duchy, policy makers were concerned that continued economic growth and its impacts on the built environment would compromise green space, which was (a) tied to quality of living associated with single family home ownership; and (b) a threat to local biodiversity; and (c) perceived to be in limited quantity. However, these concerns are tempered by prevailing values and traditions. These include desires to own a single-family house and some land, to maintain a certain quality of living, and to retain green space as a part of one's living environment. This is reinforced by a government that upholds the ideology of home ownership as key to local social cohesion. A sense of these traditions is indicated by the following quotations:

Our government declared it as a specific goal [...] that private home ownership is 
the best instrument available in order to maintain social cohesion (Interview, Government Official from the Ministry of Housing, 2012).

One difference between Luxembourg and other countries is that we have, probably by far, the highest proportion of owners and a very low proportion of renters. And, the normal Luxembourgish ideal is to have a single-family house with green around it and the next neighbour perhaps $100 \mathrm{~m}$ away. So, social housing, for example, which normally means that many people will live together sharing a smaller property is against the Luxembourg ideal (Interview, Representative from Caritas, 2012).

I look back at my parents' generation. They built a large house on a large piece of property, which was comparatively cheap at the time. That was the fashion in the 1970s. Today, those houses are certainly seen as luxury homes. But in the 1990s, a lot of immigrants arrived who could afford very large houses. Those who came to work in the banks, for example. They earned a lot of money and bought gigantic houses, and this, of course caused the market to heat up (Interview, Mortgage Broker, 2012).

Luxembourg has a regulatory system in place that controls land use and development. This system is organized over a two-tiered government whereby, generally, the central government oversees international relations and general issues of national interest, and the 106 municipalities manage schooling, waste and water, forestry, and land-use zoning. Land use is regulated by, first, the "Housing Pact" (Pacte Logement, PL) (ML, 2008), which redistributes central government funds to the municipalities according to population growth indicators. Second, and more importantly, municipal land use plans (plan d'aménagement general, PAG) need to be drawn up by each municipality, submitted and approved by various departments of the central government. With the exception of the City of Luxembourg, municipalities are generally sparsely staffed and often contract planning work out to architects, developers, or real estate agents to complete the necessary plans and carry out the procedures (Interviews, Municipal Official, 2012; Architects, 2012). The overall procedure has been the source of much frustration among the municipalities:

For me [a lawyer], it is genius. It is impossible to understand anything at all. I need a lawyer here who is doing nothing else all day except paying attention that we are aware of all the different laws and so on. I think that if they continue like this, in five years, it will be impossible to build a house without a lawyer [...] I saw the Minister at a meeting, and I told him, 'Listen, this is impossible, what you are doing,' and he told me, 'Yes, this way I have the possibility to cancel nearly any PAG,' and I answered him, 'And so do I.' And from this moment on, it is a national sport to attack any PAG (Interview, Housing Lawyer, 2012).

Not only are procedures complicated, but plans are often sent back to the municipalities with objections from different departments within the central government that conflict with one another (Interviews, Municipal Officials and Architects, 2012). This frustration over procedures that are seen as too long and non-transparent, leaves many suspicious of central government and what their intentions might actually be (Carr, 2014; Hesse, 2015; Becker et al., 2016). 
In parallel to this process, many in central government began voicing the opinion that new visions, laws, and plans were needed to meet the new challenges of the times, to address changes in the structure of Luxembourg's economy, and the associated dilemmas of growth pressure. In the early 2000s the Ministry of the Interior (Ministère de l'Intérieur, MI) introduced the notion of national spatial planning, with a strong central government role for the Department of Spatial Planning (Département de l'aménagement du territoire, DATer). Sustainable development was seen as the antidote to problems of growth pressure (Carr, 2011).

The most substantive expression of the Duchy's commitment to sustainable development came with the publication of the "National Plan for Sustainable Development" (Plan National pour un Développment Durable, PNDD) (Ministère du Développement durable et des Infrastructures (MDDI) \& Spangenberg, 2011). This was Luxembourg's response to the Rio conference and was the final product of over a decade of internal deliberation, revision, and support throughout the MDDI (Carr, 2013). Subsequently the government published the "National Spatial Plan" (Programme Directeur d'Aménagement de territoire, PDAT) (MI, 2003), which provided a vision for Luxembourg's future spatial development. It called for a polycentric and complementary relationship between urban and rural regions with higher density settlements built closer to centres of economic activity and nodes of development connected by public transport. Those involved in the development of the PDAT claimed that the strategy would deliver the optimal use of space and resources and thereby mitigate growth pressures, curb sprawl, preserve green space and deliver sustainable development (MI, 2003: 17).

In theory, the PDAT and PNDD might have appealed to residents and stakeholders as these documents spoke to issues of optimizing growth in spatial terms while maintaining standards of living and associated relationships to green space. However, while the PNDD was potentially damaging to the business-as-usual approach to property development and growth, it was never foreseen to have any legal traction. It was meant to serve merely as an information piece. The PDAT, by contrast, was earmarked as a possible solution to spatial planning problems that would obtain legal ratification. However, it ultimately failed to gain full public support not only because of the intractable procedures that came along with it, but also because its supporters never managed to achieve a sense of trust among the municipalities:

The Sector Plans, they are supposed to be finished soon and I am really afraid that we will get yet another dictate from above, while not a single word has been uttered to the Municipalities. The Municipalities are vying for their rights to selfdetermination, and I believe that there is going to be some friction (Interview, Member of the Green Party, 2012).

After more than ten years in the waiting, the legal grounding for the PDAT was announced. Krieger (2014), a well-known local advocate for property owners, published a commentary in the largest daily newspaper, Luxemburger Wort, claiming that the ministry was attempting to shut down public debate, as municipal authorities and citizens would have only three weeks to respond to the central government's new spatial planning law. Within months, the law was tossed out. The result was ultimately a stalemate over land use planning between government and private actors, defaulting to business-as-usual approaches to property development and growth 
pressure, i.e. continued speculation to the benefit of land owners, traffic problems, threats to green space, uneven disparities between labour and Luxembourgish residents. Thus, despite a tradition of strong central government, the inviolable position of developers and large land owners was left unchallenged.

Given that procedures of the PAG were already in place to regulate land use, an outsider could ask what the point of the whole PDAT exercise was, especially since it, along with its message of sustainable development, was seen by some a means of scaling up authority over land-use to the central government. Was it a genuine attempt to bring about change that would be in line with Rio objectives? Was it an attempt to rein in and centralize control over land use, and steer profits towards certain networks? Was the whole exercise simply a political charade, or "sport" as one interviewee named it, to make it feel like something would happen only to veil business as usual practices? While the answers are perhaps unclear, the story of Luxembourg remains that of an economic 'boomtown' that adopted the principles of sustainable development to internalize the externalities of rapid growth, especially those externalities believed to compromise quality of life. In this way, Luxembourg's institutional responses to growth pressures were no different than our other two examples of 'smart growth' in the US and 'sustainable development' in the $\mathrm{UK}$, as the rhetorical moves made involved playing on local traditions in order to rein in authority over land use and develop future markets. While on paper, the PDAT claimed to aim for sustainable development, in practice it aimed to preserve national sovereignty and quality of life without disturbing associated systems of private property and governance.

\section{Conclusion}

Our focus in this paper has been to examine how three different city-regions sought to manage the contradictions of rapid growth and, in particular, their perceived need to maintain economic growth trajectories while preserving environment, quality of life, and issues such as affordable housing, sprawl, and increased commuting. Theoretically we have argued that an interpretive institutionalist account helps elucidate how the actions of actors in particular places reflect both their inherited histories and the ways that they shape these through their own cultural and material contexts. A key starting point has been 'struggles over different ways of conceiving of and responding to constructed dilemmas' (Bevir and Rhodes, 2005: 180). Thus, this initial focus helps to show how dilemmas, and the ways in which they are constructed, have forced actors to reconsider beliefs and traditions. At the same time though, those same beliefs and traditions have helped shape institutional responses to address the dilemmas. Solutions to dilemmas will be strategically selected, but not in some pure ideological form, they take the shape of traditionaland dominant-ideas and prevailing institutional structures. Change is most likely to come about when proponents can demonstrate continuity with pre-existing traditions. Hence, those competing ideas that best fit into existing traditions and practices may be acceptable, whereas more radical alternatives may not.

In our case study examples, the dilemmas share much common ground (Table 2). Concerns over sprawl, housing affordability, open space preservation, congestion, and quality of life combined with fears over the loss of global economic competitiveness were prevalent in Boston, South East England, and Luxembourg. Yet the ways in which these dilemmas have been addressed and 
the institutional forms that emerged to implement policy solutions have varied beyond simple paradigms. In Boston, the response to the dilemmas has been shaped by local traditions of political fragmentation and a longstanding concern for affordable housing. While the extent of political fragmentation may be exaggerated (see Horan, 2009), it still acts as a local tradition that needs to be accommodated through dialogue and community engagement in the MetroFuture project. Similarly, while the affordable housing agenda may be a relic of a more liberal past, it has taken on a new importance in local concerns over retaining global competitiveness and attractiveness to new economy firms and employees. The adoption of smart growth as a response to dilemmas has so far managed to build on traditions and provide the medium through which differing beliefs can largely be reconciled. Whether this can continue to be a valid response, given the tensions between beliefs, remains to be seen. In the UK, there were similar dilemmas, which were especially prevalent in the rapidly growing economy of London and the South East England. Here though, traditions of redistribution and fairness under a Labour government shaped the institutional responses largely through changes to the planning system. As with Boston, these changes were increasingly market-driven, especially with a change to a Coalition government (and even more so subsequently with a change to a Conservative government), although in the UK change has been a top-down process, with central government imposing changes in planning regulations on local areas, reflecting longstanding traditions of central-local relations in the UK. This devolved approach, in contrast to the Boston experience, imposed market reform obliquely. For example, in the UK the central government established housing targets for local authorities. While, prima facie, this may not seem to be a 'market' reform it has the implications of one because it forces local authorities to develop a minimum amount of housing or, as a consequence, lose some central government funding. Thus, local authorities have to 'open up' their regulatory process to satisfy this demand. In Luxembourg, the dilemmas have an additional dimension where congestion and planning concerns have been shaped by Luxembourg's changing economic role and particularly by the resultant inward commuting patterns from other countries. However, despite central government attempts to impose strong planning and land use measures, the reality has been the continued prevalence of local traditions of government at commune level and a resultant lack of transparency in land use planning decisions that have often favoured local elites and market development. Furthermore, as a result of the government focusing on getting its command and control regime 'right' the market altered space so much that these goals are obsolete.

Examining three cases, rather than a single one, provides conceptual insights into how dilemmas, though similar across space, are managed differently in place. We believe the merits of an interpretive approach lie in its focus on the 'complex and continuous process of interpretation, conflict, and activity that produces ever-changing patterns of rule' (Bevir, 2006: 11) and its ability to help explain institutional fluidity and dynamism. These qualities can help to inform the 'cultural economies' literature outlined in the introduction. First, interpretive institutionalism provides the conceptual linkages to understand institutional relations in ways that one can observe the broad cultural characteristics that inform the development and evolution of economies. Hence, it also provides an empirical window into how actors who are part of broader traditions, with beliefs of their own, shape the understanding of, and responses to, policy dilemmas. These perceived dilemmas, in turn, can shape and reshape economic governance. Importantly, from the view of North's (2015) work, it can reveal how capitalist social relations are reproduced, or, how new ideas, such as those consistent with diverse economies, can shape 
new forms of economic development. For example, one could explore how non-capitalist ideas might emerge through beliefs that alter traditions. Interpretive institutionalism also provides the conceptual footing to reveal the multiple and different causal pathways that shape responses to perceived dilemmas.

In the future, research will be needed to examine new governance failures that will play into a situation where beliefs and traditions have evolved through smart growth policies, which will lead to different ways of framing, and responding to, these new dilemmas (Bevir, 2006). We are already beginning to see these at the local level through initiatives such as the transition towns and sharing movements. There is also room to expand the conceptual scope of interpretive institutionalism. For example, our work here, and that of Bevir and Rhodes, is focused on formal politics and political institutions. The scope could be widened to examine the informal politics that shapes these concepts of dilemmas, traditions, and beliefs.

Acknowledgement. This research was funded by the $<<$ BLINDED FOR REVIEW) . The authors are grateful to the reviewers for their helpful comments. Finally, we'd like to thank the editor, <<BLINDED FOR REVIEW) and the special issue editors < <BLINDED FOR REVIEW) for their efforts to improve this manuscript.

\section{References}

Affolderbach J, Carr C, 2016, "Blending Scales of Governance: Land - Use Policies and Practices in the Small State of Luxembourg" Regional Studies 50 944-955

Allmendinger P, Haughton G, 2011, "Challenging localism" Town and Country Planning 80(7/8) 314-317

Anderson, Geoff. "Why smart growth: A primer." (1998).

Barker K, 2004, "Barker Review of Housing Supply" HM Treasury http://www.hmtreasury.gov.uk/consultations_and_legislation/barker/consult_barker_index.cfm.

Barnes T, 1996, The Logics of Dislocation (Guilford, New York)

Becker T, Krueger R, Hesse M (2016) "Hiding the Hidden Hand: Essentialism, AntiEssentialism, and the Science-Policy Interface" Paper presented at the Royal Geographical Society, London, August.

Bevir M, 1999, "Foucault, power, and institutions" Political Studies 47(2) 345-359

Bevir M, 2003, "Narrating the British state: An interpretive critique of New Labour's institutionalism" Review of International Political Economy 10(3), 455-480

Bevir M, 2006, "The life, death and resurrection of British governance" 
Australian Journal of Public Administration, 1(65), 59-69

http://repositories.cdlib.org/postprints/2580

Bevir M, Rhodes R, 2001, “A Decentered Approach to Governance: Rational choice, institutionalism and interpretation” Working Paper 2001- 10, UC Berkeley

Bevir M, Rhodes R, 2006, Governance Stories (Routledge, London)

Bevir M, Rhodes RA, 2012, "Interpretivism and the analysis of traditions and practices " Critical policy studies $\mathbf{6}(2)$ 201-208

Bevir, Mark, Rod AW Rhodes, and Patrick Weller. "Traditions of governance: interpreting the changing role of the public sector." Public Administration 81, no. 1 (2003): 1-17.

Carr, C. (forthcoming) "Sustainability in small states: Luxembourg as a post-suburban space under growth pressure in need of a cross-national sustainability" In Brinkmann, Robert, and Garren, Sandra J. (Eds.) "The Palgrave Handbook of Sustainability: Case Studies and Practical Solutions," New York: Palgrave-Macmillan.

Carr C, 2011, "Luxembourg sustainable spatial development policy: General milestones and circuits (SUSTAINLUX),"

https://orbilu.uni.lu/bitstream/10993/1853/1/SUSTAINLUX_WP2.pdf

Carr C, 2014, "Discourse Yes, Implementation Maybe: An Immobility and Paralysis of Sustainable Development Policy," European Planning Studies 22(9) 1824-1840

Chang C, forthcoming, Building Ecopolis in the World's Factory: A Field Note on SinoSingapore Tianjin Eco-city, R Krueger, et al, Adventures in Sustainable Urbanism, Cambridge: MIT.

Chilla T, Schulz C, 2015, "Spatial Development in Luxembourg: Mimetic Evolution or Emergence of a New Planning Culture?” European Planning Studies 23(3) 509-528

Christmann N, 2017, "Wohnmobilität in der Großregion eine interurbane Diskursanalyse mit Fokus auf den Städten Arlon, Thionville und Trier," Dissertation defended October 19, 2017, at the University of Luxembourg, Luxembourg.

Coaffee J, Healey P, 2003, “'My voice: my place': Tracking transformations in urban Governance" Urban Studies 40(10) 1979-1999

Communities and Local Government (CLG), 2006, "Strong and Prosperous Communities: The local government White Paper" https://www.gov.uk/government/publications/strong-andprosperous-communities-the-local-government-white-paper

DiGaetano, A and E Strom (2003) Comparative urban governance: An integrated approach, Urban Affairs Review, 38(3), 356-395 
Durant, R (2006) Agency Evolution, New Institutionalism, and 'Hybrid' Policy Domains: Lessons from the 'Greening' of the U.S. Military, Policy Studies Journal 22, 469-490

Frank, S (forthcoming) Middle-Class Family Enclavism and Solidarity from a Distance: Notes from a Field of Contradictions, in R Krueger, et al, Adventures in Sustainable Urbanism, Cambridge: MIT.

Gertler, Meric S. "Tacit knowledge and the economic geography of context, or the undefinable tacitness of being (there)." Journal of Economic Geography 3, no. 1 (2003): 75-99.

Gibbs D, Krueger R, 2012, "Fractures in Meta - Narratives of Development: An Interpretive Institutionalist Account of Land Use Development in the Boston City - Region" International Journal of Urban and Regional Research 36(2) 363-380

González, Sara, and Patsy Healey. "A sociological institutionalist approach to the study of innovation in governance capacity." Urban Studies 42, no. 11 (2005): 2055-2069.

Hesse M, 2014, "On borrowed size, flawed urbanisation and emerging enclave spaces" European Urban and Regional Studies doi: 10.1177/0969776414528723

Hesse M, Gouvernementalität - Die "Steuerung der Steuerung" Forum für Politik, Gesellschaft und Kultur in Luxemburg, 350 23-35

Hesse M, Becker T, 2010, “Internationalisierung und Steuerung metropolitaner Wohnungsmärkte, Das Beispiel Luxemburg” Informationen zur Raumentwicklung 5/6 403-415

Horan C, 2009, "The politics of competitive regionalism in Greater Boston" Journal of Urban Affairs 31(3) 349-369

Irazábal C, 2005, Urban Governance and City Making in the Americas: Curitiba and Portland (Ashgate, London)

Jonas A, While A, Gibbs D, 2010, "Managing infrastructural and service demands in new economic spaces: The new territorial politics of collective provision" Regional Studies 44(2) $183-200$

Krieger, G. 2014, "Den domme Bierger"

Luxembourger Wort, available at http://www.krieger-avocats.lu/blog/blogdetail.html ?blogidarticle $=142 \&$ blogstartmonth=2\&blogmonthback=-1\#.Wfc7aEyZO9Y (Accessed October 30, 2017)

Krueger R, Gibbs D, 2010, “Competitive global city regions and sustainable development': an interpretive institutionalist account in the South East of England" Environment and planning A 42 821-837 
Lowndes V, Wilson D, 2001, "Social capital and local governance: Exploring the institutional design variable" Political Studies 49 629-647

Lowndes V (2005)

Mansfield B, 2004, "Rules of privatization: contradictions in neoliberal regulation of North Pacific fisheries" Annals of the Association of American Geographers 94(3) 565-584.

Mayor of London (2017) London Plan Annual Monitoring Report 2015-16, Greater London Authority: London.

MAPC (Metropolitan Area Planning Council)) (2007) "Which way to a Greater Boston region?" (MAPC, Boston, MA)

MAPC (Metropolitan Area Planning Council) (2008) "MetroFuture regional plan: goals, objectives, and draft implementation strategies” (MAPC, Boston, MA)

Marom N, 2014, "Relating a city's history and geography with Bourdieu: One hundred years of spatial distinction in Tel Aviv" International Journal of Urban and Regional Research 38(4) $1344-1362$

Midheme E, Moulaert F, 2013,'Pushing back the frontiers of property: Community land trusts and low-income housing in urban Kenya" Land Use Policy 35 73-84

Ministère du Logement (ML), 2008, "Pacte Logement" http://www.ml.public.lu/fr/politiquelogement/pacte-logement/

Ministère de L'Intérieur (MI), 2003, 'Programme Directeur D'Aménagement du Territoire'. Le Gouvernement du Grand-Duché de Luxembourg. National Planning Policy Framework, https://www.gov.uk/government/uploads/system/uploads/attachment_data/file/6077/2116950.pdf

Ministerium für Nachhaltige Entwicklung und Infrastrukturen (MDDI), Spangenberg J H, 2011, "PNDD Luxembourg: Ein Nachhaltiges Luxembourg für Mehr Lebensqualität" http://www.developpement-durable-infrastructures.public.lu/fr/developpement-durableinfrastructures/version_integrale/PNDD_PDF_deutsch_integral.pdf

Murphy J T, 2015, "Human geography and socio-technical transition studies: Promising intersections" Environmental Innovation and Societal Transitions 17 73-91

National Planning Policy Framework (NPPF), 2012,

North, P. "The business of the Anthropocene? Substantivist and diverse economies perspectives on SME engagement in local low carbon transitions." Progress in Human Geography (2015): 309-325. 
Olds K, 2001, Globalization and urban change. Capital, Culture and Pacific Rim (Oxford University Press, Oxford)

Peck, J. "Geography and public policy: constructions of neoliberalism." Progress in Human Geography 28, no. 3 (2004): 392-405.

Peck J, 2010, Constructions of neoliberal reason (Oxford University Press, Oxford)

Planning Inspectorate, 2012, http://www.planningportal.gov.uk/planning/planninginspectorate, accessed July 15, 2015.

Portney K E, 2003, Taking Sustainable Cities Seriously: Economic Development, the Environment, and Quality of Life in American Cities (MIT Press, Cambridge)

Raco M, 2005, "Sustainable development, rolled-out neo-liberalism and sustainable communities" Antipode 37(2) 324-346

Rhodes, R A W. "From marketisation to diplomacy: It's the mix that matters." Australian Journal of Public Administration 56, no. 2 (1997): 40-53.

Rosol M, 2013, “Vancouver's “EcoDensity” Planning Initiative: A Struggle over Hegemony?” Urban Studies DOI: 0042098013478233.

STATEC, 2015, "Luxembourg in Figures. Institute national de la statistique et des études économiques" http://www.statistiques.public.lu/catalogue-publications/luxembourg-enchiffres/2015/luxembourg-figures.pdf

STATEC, 2016, "Emploi et chrômage par mois 195-2016", http://www.statistiques.public.lu/stat/TableViewer/tableView.aspx?ReportId=5237\&IF_Languag $\mathrm{e}=$ fra $\&$ MainTheme $=2 \&$ FldrName $=3$

Thrift N, Olds K, 1996, "Refiguring the economic in economic geography" Progress in human Geography 20(3) 311-337.

While, A, Gibbs, D and Jonas, A (2013) The competition state, city-regions, and the territorial politics of growth facilitation, Environment and Planning A, 45, 2379-2398.

Yeung, H Wai-chung (2003), 'Practicing new economic geographies: a methodological examination', Annals of the Association of American Geographers, 93(2), 442-62.

Zegart A, B. "Flawed by design: The evolution of the CIA, JSC, and NSC. Palo Alto." (1999). 
Table 1. Analytical Concepts of Interpretive Institutionalism

\begin{tabular}{|c|l|}
\hline Concept & \multicolumn{1}{|c|}{ Operant } \\
\hline Dilemmas & $\begin{array}{l}\text { Perceived paradox of existing policy. These stand in opposition to } \\
\text { existing beliefs but are understood in a particular ideological or political } \\
\text { tradition. Agents, or coalitions of them, situated in different traditions } \\
\text { construct these contradictions. }\end{array}$ \\
\hline Traditions & $\begin{array}{l}\text { This is the social context in which actors exercise their reason and actions } \\
\text { (e.g., 'Old' Labour and 'New' Labour outlined in the text). Individuals are } \\
\text { thus not trans-historical actors, but have a sort of bounded rationality. }\end{array}$ \\
\hline Beliefs & $\begin{array}{l}\text { Offer analytical priority as to how individuals construct their world, } \\
\text { including the ways they understand their location, the norms that affect } \\
\text { them and their interests. }\end{array}$ \\
\hline
\end{tabular}


Table 2. Dilemmas, Traditions and Responses across three City-Regions

\begin{tabular}{|c|c|c|c|c|}
\hline $\begin{array}{l}\text { City- } \\
\text { Region }\end{array}$ & Dilemmas & Traditions & Beliefs & Responses \\
\hline Boston & & $\begin{array}{l}\text { Concern for } \\
\text { affordable housing, } \\
\text { Political } \\
\text { fragmentation } \\
\text { (Home Rule) }\end{array}$ & & Smart Growth \\
\hline $\begin{array}{l}\text { South } \\
\text { East }\end{array}$ & $\begin{array}{l}\text { How does a city or } \\
\text { region grow, } \\
\text { maintain } \\
\text { competitiveness, } \\
\text { attract new } \\
\text { economy workers, } \\
\text { and maintain } \\
\text { quality of life } \\
\text { WHILE }\end{array}$ & $\begin{array}{l}\text { Tradition of fairness } \\
\text { in distribution of } \\
\text { wealth }\end{array}$ & $\begin{array}{l}\text { More housing, } \\
\text { with a more } \\
\text { efficient } \\
\text { planning } \\
\text { system }\end{array}$ & $\begin{array}{l}\text { Design excellence, } \\
\text { social well-being, } \\
\text { and environmental } \\
\text { responsibility } \\
\text { Sustainable city- } \\
\text { region could be an } \\
\text { engine for } \\
\text { economic growth, } \\
\text { not a hindrance } \\
\text { Market driven }\end{array}$ \\
\hline $\begin{array}{l}\text { Greater } \\
\text { Luxem- } \\
\text { bourg }\end{array}$ & $\begin{array}{l}\text { dealing with } \\
\text { planning } \\
\text { consequences } \\
\text { housing costs, } \\
\text { sprawl, transport } \\
\text { inequality }\end{array}$ & $\begin{array}{l}\text { Managing as a city- } \\
\text { region and as a small } \\
\text { state } \\
\text { Maintenance of } \\
\text { international } \\
\text { relations by higher } \\
\text { level authorities. } \\
\text { Protecting private } \\
\text { property } \\
\text { Protecting } \\
\text { centralized } \\
\text { regulation }\end{array}$ & $\begin{array}{l}\text { New spatial } \\
\text { planning laws } \\
\text { Sustainable } \\
\text { development }\end{array}$ & $\begin{array}{l}\text { Attempted } \\
\text { centralization } \\
\text { (through the } \\
\text { PDAT) } \\
\text { Market-based } \\
\text { solutions to } \\
\text { housing problems } \\
\text { (PL) }\end{array}$ \\
\hline
\end{tabular}

